5. Нова українська школа. Концептуальні засади реформування середньої школи. URL: https://mon. gov.ua/storage/app/media/zagalna $\% 20$ serednya/novaukrainska-shkola-compressed.pdf (дата звернення: 23.08.2020).

6. Фізика. 7-9 класи. Навчальна програма для загальноосвітніх навчальних закладів. URL: https:// ru.osvita.ua/school/program/program-5-9/56124/

7. Sclater N. Web 2.0, Personal Learning Environments, and the Future of Learning Management Systems (Research Bulletin, Issue 13). Boulder, CO: EDUCAUSE Center for Applied Research. 2008. URL: http://www.educause.edu/ecar (дата звернення: 23.08.2020).

8. Blum B. Handbook on formative and summative evaluation of student learning by Blum. Madaus, 1971.

9. Bonk C. Graham C. Handbook of blended learning: Global perspectives, localdesigns. SanFrancisco, CA: PfeifferPublishing, 2005.
10. Sclater N. Web 2.0, Personal Learning Environments, and the Future of Learning Management Systems (Research Bulletin, Issue 13). URL: http://www.educause.edu/ecar (дата звернення: 23.08.2020).

11. Siemens G. Connectivism: A Learning Theory for the Digital Age. International Journal of Instructional Technology and Distance Learning. 2005. Vol. 2. No. 1. URL: http://www.elearnspace.org/Articles/connectivism.htm (дата звернення: 01.09.2020).

12. Saadatmand M., Kumpulainen K. Emerging Technologies and New Learning Ecologies: Learners' Perceptions of Learning in Open and Networked Environments. Proceedings of the 8th International Conference on Networked Learning / Department of Teacher Education, University of Helsinki ; Edited by: V. Hodgson, C. Jones, M. Laat, D. McConnell, T. Ryberg, P. Sloep. 2012. P. 266-275.

Дата надходження до редакиї: 16.09.2020 p.

Тарас ГАЛАТЮК,

учитель фізики та інформатики

ЗЗСО № 6 м. Рівного, магістр фізики

Юрій ГАЛАТЮК, кандидат педагогічних наук, професор, професор кафедри фізики, астрономії та методики викладання

Рівненського державного гуманітарного університету

\title{
ФОРМУВАННЯ МЕТОДОЛОГІЧНОЇ КУЛЬТУРИ УЧНІВ З ФІЗИКИ У ПРОЦЕСІ ТВОРЧОЇ ПІЗНАВАЛЬНОї ДІЯЛЬНОСТІ
}

У статті акиентується увага на формуванні креативного і продуктивного компонентів методологічної культури учнів у контексті реалізації Концепиії Нової украӥнської школи. Доведено, щзо повноцінне формування означених компонентів не можливе без залучення учнів до творчої пізнавальної діяльності. Розкриваються теоретичні та практичні механізми організачії творчої навчально-пізнавальної діяльності під час вивчення фізики у контексті формування методологічної культури учнів, засвоєння методологічних знань та компетентностей. Аналізується творча пізнавальна діяльність як предмет проєктування $і$ організачї вчителем навчальної діяльності. Схарактеризовані проиес моделювання та організації творчої пізнавальної діяльності на основі виконання фізичних дослідів та навчального спостереження.
Ключові слова: методологічна культура, педагогічне проєктування, творча пізнавальна діяльність, навчальне спостереження.

The article focuses on the formation of creative and productive components of the methodological culture of students in the context of the implementation of the concept of the New Ukrainian school. The full formation of these components is not possible without involving students in creative cognitive activity. Creative cognitive activity is the subject of design and organization by the teacher.

Theoretical and practical mechanisms of organization of creative educational and cognitive activity during the study of physics in the context of formation of methodological culture of students, assimilation of methodological knowledge and competencies are revealed. 
It is a question of modeling and the organization of creative cognitive activity on the basis of performance of physical experiments and educational supervision.

The place and role of experimental tasks are analyzed, which involve students in performing simple physical experiments and educational observations. As practice shows, such tasks, especially during the study of the basic course of physics, can serve as an effective means of problem-based content of creative cognitive activity. In the process of their implementation, the transformation of reproductive activity into creative activity is realized on the basis of the manifestation of cognitive initiative and awareness of the by-product of reproductive activity.

The mechanisms and means of management of cognitive activity on the basis of indirect influence are revealed, which promote mastering of the orienting basis of activity and formation of the basic components of methodological culture of pupils. Experimental tasks performed on the basis of successfully selected by the teacher guidelines are perceived by students not as reproductive but as creative.

Key words: methodological culture, pedagogical design, creative cognitive activity, educational observation.

Постановка проблеми. Організація освітнього процесу у контексті Концепції Нової української школи [6], реалізація сучасних освітніх стандартів вимагають пошуку нових дидактичних механізмів щодо впровадження діяльнісного підходу у процес навчання окремих предметів, зокрема фізики. Чому ми акцентуємо увагу саме на діяльнісному підході? Першочергово, це пов'язано з тим, що теоретичні й практичні аспекти проєктування та організації навчально-пізнавальної діяльності є основою формування ключових компетентностей - динамічних, інтегральних характеристик учнів, які включають відповідні знання, уміння, навички, ціннісно-мотиваційні, етичні, естетичні орієнтири тощо. Проте будь-яка діяльність характеризується власною методологією [7], що виявляється у методологічній культурі іiі суб'єкта. Це стосується і навчальної діяльності, суб'єктом якої є учень.

Запропонована й апробована нами цілісна дидактична модель методологічної культури учня включає такі базові структурні компоненти: ціннісно-мотиваційний; гносеологічний; предметно-змістовий; інформаційно-комунікативний; морально-етичний; операційно-діяльнісний; естетичний, організаційно-рефлексивний; креативний; продуктивний (діяльнісний досвід) [2].

Креативний і продуктивний компоненти $є$ ключовими в ієрархії запропонованої моделі. Перший об'єднує в собі творчі якості учня, які проявляються у процесі діяльності, постановки й розв'язання пізнавальних проблем в умовах обмеженості наявної інформації, пошуку оригінальних підходів, стратегій на основі домінування механізмів інтуїтивного мислення. Другий компонент відображає суб'єктивний досвід пізнавальної діяльності, яка здійснюється відповідно до певної процедури: суб'єкт пізнання здобуває досвід, що є продуктом пізнавальної діяльності.

Повноцінне формування згаданих компонентів не можливе без залучення учнів до творчої пізнавальної діяльності, яка $є$ предметом проєктування і організації з боку вчителя.

Аналіз наукових досліджень і публікацій. У попередніх наших публікаціях було розкрито зміст та структуру методологічної культури учнів у процесі вивчення природничих предметів [2], досліджено психолого-дидактичний зміст творчої пізнавальної ситуації у контексті формування методологічної культури [3]. В основі теоретичного обгрунтування результатів дослідження - наукові праці, присвячені методології у навчанні (С. Гончаренко, О. Новіков, Е. Юдін, В. Штофф), психологічним аспектам творчості та культури особистості (Д. Богоявленська, Г. Балл, І. Колошина, О. Пономарьов, О. Лук); теорії діяльнісного навчання (Г. Атанов, Г. Костюк, О. Леонтьєв, В. Давидов), організації творчої діяльності у навчанні фізики (А. Давиденко, М. Шут, В. Разумовский, Г. Касянова, Р. Швай та ін.).

Вивчення наукових праць, присвячених психології творчості, засвідчує, що методологічні знання $\epsilon$ орієнтовною основою творчої діяльності, а психологічний механізм пізнавальної творчості, як правило, полягає у фіксації побічного продукту [9], прояві інтелектуальної (пізнавальної) ініціативи, у постановці проблеми, що випливає з результатів репродуктивної діяльності [1].

Мета статті - проаналізувати теоретичні та практичні механізми організації творчої навчально-пізнавальної діяльності під час вивчення фізики у контексті розвитку методологічної культури учнів. Зокрема, йдеться про моделювання та організацію творчої діяльності на основі фізичного досліду та навчального спостереження.

Виклад основного матеріалу. Моделюючи творчу пізнавальну діяльність, учитель повинен чітко визначати дидактичні функції, які виконує фізичний дослід у структурі діяльності. Одне і теж експериментальне завдання може визначати як репродуктивну діяльність, так і діяльність творчого характеру.

Зупинимося детальніше на основних ознаках $\mathrm{i}$ критеріях, які визначають творчу навчальну діяльність. У педагогічній психології однією із таких ознак вважається проблемність, серед інших - новизна продукту, присутність інтуїтивної здогадки (інсайту) у процесі вирішення проблеми, передбачення результату, висунення гіпотези, високий рівень інтелектуальної активності та ін.

На останньому критерії - рівні інтелектуальної активності - варто зупинитися детальніше. Так, інтелектуальна активність була запропонована Б. Богоявленською в якості «одиниці аналізу творчості». На іiі думку, інтелектуальна активність поєднує пізнавальні та мотиваційні характеристики творчої особистості, а отже, може бути одиницею дослідження іiї творчого потенціалу [1]. Поєднуючи в собі інтелектуальні (розумові здібності) і неінтелектуальні (особистісні, мотиваційні) фактори розумової діяльності, інтелектуальна активність не зводиться ні до тих, ні до інших. Інтелект (знання, розумові здібності) створює фундамент інтелектуальної активності, але проявляється у творчій діяльності через мотиваційну структуру особистості [1]. Тобто, творчість - це похідна інтелекту, заломленого через мотиваційну структуру, яка або гальмує, або стимулює його прояв. Інтелектуальна активність виражається інтелектуальною ініціативою. Якщо коротко, то інтелектуальна ініціатива це продовження пізнавальної діяльності поза межами вимоги (задачі), тобто після успішного досягнення суб' єктом цілей, які були перед ним поставлені.

На наш погляд, пізнавальна ініціатива - це та ланка, посередництвом якої може відбуватися перетворення репродуктивної діяльності у творчу [3; 4]. 
За такої умови детермінантою творчої діяльності не обов'язково має бути проблема, сформульована у вигляді фізичної задачі, у іiі традиційному розумінні. Цю функцію може виконувати завдання репродуктивного характеру, у якому латентно присутня можливість прояву учнем інтелектуальної ініціативи.

У чому має проявлятися така ініціатива? Насамперед, у формулюванні нової проблеми і самостійному прагненні до іiі вирішення. Недаремно формулювання проблеми, а також пов'язане 3 ним складання учнями фізичних задач, розглядається у теорії і методиці навчання як ознака творчості, як вид навчальної діяльності, що сприяє розвитку творчих здібностей [8].

Інтелектуальна ініціатива, що проявляється як формулювання навчальної проблеми в результаті виконання нескладних фізичних дослідів чи спостережень, узгоджується 3 концепцією творчості, розробленою Я. Пономарьовим. Одним із положень цієї концепції $є$ визнання неоднорідності результату людської діяльності - наявність в ньому прямого (усвідомлюваного) і побічного (неусвідомлюваного) продукту. «Побічний продукт, на думку Я. Пономарьова, невід'ємна частина будь-якого результату усвідомлюваної і цілеспрямованої діяльності, та іії частина, яка до усвідомлення не може бути піддана мимовільній логічній обробці» [9, с. 467]. Побічний продукт об'єктивно виникає поза прямою залежністю від свідомо поставленої цілі діяльності, тому, як правило, не усвідомлюється суб'єктом. Саме здатність побачити (усвідомити) побічний продукт цілеспрямованої діяльності і $є$ однією із основних ознак творчості.

Зважаючи на зазначене вище, суть креативності як психологічної якості особистості зводиться до інтелектуальної активності та чутливості до побічних продуктів діяльності. Творчій людині притаманні інтелектуальна ініціатива і здатність бачити побічні результати діяльності, які характеризуються новизною і $€$ творчими. Людина, у якої несформовані такі якості, бачить лише прямі продукти діяльності, тобто ті, які були наперед запланованими і не помічає новизни у результатах своїх дій.

Викладені вище теоретичні положення щодо творчої діяльності $є$ основою для проєктування та організації творчої навчальної діяльності на основі фізичних дослідів і спостережень у контексті виконання, на перший погляд, репродуктивних експериментальних завдань. Розглянемо приклад.

\section{Завдання}

Виконується учнями в 7-у класі перед вивченням теми «Виштовхувальна сила в рідинах і газах. Закон Архімеда».

Обладнання: три пробірки, кожна 3 яких на третину заповнена водою, соняшниковою олією, етиловим спиртом; піпетка.

\section{Зміст}

1. За допомогою піпетки, крапніть краплину води у пробірку з олією. Спостерігайте за поведінкою краплини. Вона плаває на поверхні олії чи тоне? Яку форму має краплина?

2. Крапніть краплину олії у пробірку з водою. Виконайте аналогічні спостереження.

3. Крапніть краплину олії у пробірку із етиловим спиртом. Спостерігайте за тим, тоне чи плаває краплина?

4. За допомогою піпетки у пробірку зі спиртом добавляйте воду, роблячи це повільно, краплина за краплиною. Спостерігайте за поведінкою краплини олії.
5. Виконайте досліди 2-4, замінивши краплину олії клаптиком парафіну.

6. Опишіть результати спостережень, проведених у ході виконання цих дослідів. Зробіть їх порівняння. Сформулюйте висновки.

Учні будуть спостерігати наступне: поміщена в олію краплина води, прийнявши форму кулі, опускається на дно; краплина олії плаває на поверхні води, але тоне в спирті; по мірі добавляння до спирту води, краплина олії, що лежить на дні у вигляді сплюснутої кульки, набирає правильної кулястої форми, а потім повільно починає підніматися вгору. Теж саме (щодо плавання і занурення) буде відбуватися із клаптиком парафіну.

Якого результату від учнів потрібно очікувати вчителю? У даному випадку можливі такі варіанти:

Bapiaнm 1. Учитель очікує лише репродуктивних дій. Такі дії, власне, і передбачені пунктами 1-5 завдання. Тоді результатом діяльності учнів будуть факти, описані вище.

Bapiaнm 2. Кінцевим результатом виконання завдання буде сформульована нова проблема на основі результатів досліду.

Як бачимо, поряд із результатами досліду (прямим продуктом діяльності: краплина води в олії тоне; краплина олії у воді плаває, а в спирті тоне; парафін у воді плаває, а в спирті тоне), які отримують учні у ході репродуктивної діяльності і які є відповіддю на вимогу завдання, існує побічний продукт. Він не одразу усвідомлюється учнями - це співвідношення кількісних характеристик речовин, зокрема їхніх густин. Із поняттям густини учні на час виконання завдання уже знайомі, тому усвідомлення ними побічного продукту, зокрема того, що факти, які спостерігаються в дослідах, пов'язані із густинами речовин, i буде творчим актом у процесі виконання цього, на перший погляд, репродуктивного завдання.

Отже, інтелектуальна (пізнавальна) ініціатива учнів має проявитися як вихід за межі діяльності, яка безпосередньо регламентується змістом завдання. Ї̈ї результатом має бути сформульована нова проблема у вигляді запитання: «Чому тіло, густина якого більша за густину рідини, тоне, а тіло $з$ меншою густиною плаває?»

Очікуючи від учнів саме такого результату, вчитель має застосовувати відповідні засоби управління навчальною діяльністю (назвемо їх засобами навчаючого впливу). Завдання вчителя - використовуючи такі засоби, «індукувати» в учнів пізнавальну ініціативу. Як правило, це засоби не прямого, а опосередкованого управління діяльністю, які виконують функцію орієнтирів узагальненого характеру, наприклад, план-орієнтир.

\section{План-оріснтир \\ Спостереження явища. \\ Нагромадження фактів}

1. Сформулюйте мету спостереження відповідно до вимоги завдання.

2. Уточніть, що є предметом спостереження, що будете спостерігати?

3. Забезпечте необхідні умови для спостереження.

4. Складіть план спостереження і запишіть його у зошит.

5. Виберіть спосіб фіксації результатів спостереження. 
6. Фіксуючи результати спостереження, звертайте увагу на те, як спостережуване явище відбувається у часі та які умови його протікання.

7. Пам'ятайте, що ціль спостереження - зафіксувати ознаки та особливості спостережуваних процесів і явищ та на основі їхнього аналізу, порівняння, узагальнення виявити певні причинно-наслідкові зв'язки, закономірності та протиріччя.

8. Сформулюйте проблемні запитання, що виникли у результаті аналізу результатів досліду?

Учні виконують експериментальне завдання, спираючись на узагальнений план-орієнтир. Таким чином, вони засвоюють орієнтувальну основу діяльності, елементи методологічних знань високого рівня узагальнення. Такі знання, згідно 3 концепцією нормативної творчої діяльності, $\epsilon$ ефективним засобом творчості учнів [5].

Висновки. Результати проведеного педагогічного дослідження свідчать, що коли завдання, подібні до розглянутих у публікації, виконуються з опорою на вдало підібрані вчителем орієнтири, то вони сприймаються учнями не як репродуктивні, а як творчі. Застосування орієнтирів дозволяє учням побачити «між рядками» змісту, на перший погляд, репродуктивного завдання, приховану в ньому ще одну вимогу, а саме: вийти за межі даного завдання, виявити протиріччя у результатах досліду, сформулювати проблему. Таким чином, діяльність набуває творчого характеру, реалізується один із визначених нами принципів організації творчої навчальної діяльності - принцип домінантного перетворення репродуктивної діяльності у творчу [3]. Особливо це актуально у контексті реалізації проблемного навчання, застосування активних дидактичних методів: евристичного, дослідницького, методу проєктів.

\section{СПИСОК ВИКОРИСТАНОЇ ЛІТЕРАТУРИ}

1. Богоявленская Д. Б. Психология творческих способностей : учеб. пособие для студ. высш. учеб. заведений. Москва : Академия, 2002. 320 с.

2. Галатюк Т. Ю. Модель методологічної культури учня в контексті вивчення природничих предметів. Збірник наукових праць Кам'янещь-Подільського національного університету імені Івана Огієнка. Серія «Педагогічна». Кам'янець-Подільський : Кам'янець-Подільський національний університет імені Івана Огієнка, 2015. Вип. 21. С. 178-181.

3. Галатюк Т., Галатюк Ю. Творча пізнавальна ситуація як чинник у формуванні методологічної культури учня. Нова педагогічна думка : науково-методичний журнал. Рівне, 2019. № 4. С. 142-145.

4. Галатюк Ю. М. Особливості проєктування творчої навчальної діяльності на основі методу спостереження. Наукові записки Рівненського державного гуманітарного університету : збірник наукових праць. Рівне : РДГУ, 2016. Вип. 14 (57). С. 32-35.

5. Калошина И. П. Структура и механизм творческой деятельности. Москва : Изд-во МГУ, 1983. 168 с.

6. Нова українська школа. URL : https://mon.gov.ua/ ua/tag/nova-ukrainska-shkola (дата звернення: 10.11.2020).

7. Новиков А. М. Методология. Москва : СИНТЕГ, 2007. 668 с.

8. Павленко А. I. Методика навчання учнів середньої школи розв'язуванню і складанню фізичних задач (теоретичні основи). Київ : Міжнародна фінансова агенція, 1997. 177 с.

9. Пономарев Я. А. Психология творения. Воронеж : Издательство НТО «МОДЭК», 1999. 480 с.

Дата надходження до редакиї: 12.11.2020 p.
Людмила ЛЕЙБИК,

викладач-методист фізики та астрономії

Луиьького педагогічного коледжу

\section{ФОРМУВАННЯ ЦІЛСНОСТІ СПРИЙНЯТТЯ СВІТУ В СТУДЕНТІВ ПЕДАГОГІЧНОГО КОЛЕДЖУ У ПРОЦЕСІ ВИВЧЕННЯ ПРЕДМЕТА «ФІЗИКА ТА АСТРОНОМІЯ»}

У статті зосереджено увагу на інтегруванні фізичних та астрономічних знань, що забезпечує системний виклад матеріалу в нових органічних взаємозв'язках, теоретичне узагальнення, розширене трактування набутих студентами знань.

Ключові слова: інтеграція, фізичний складник, астрономічний складник, ијілісність сприйняття світу.
Modern educational theory and practice prove that creativity, adaptability, critical thinking and cooperation are very valuable skills, because in a dynamic world focused on development, exchange of information and knowledge, professionals who can both combine and apply their knowledge from several disciplines are the ones with the distinct advantage. 